\title{
Migration Behaviour of Strontium in Czech Bentonite Clay
}

\author{
Lucie Baborová ${ }^{* 1}$, Dušan Vopálka ${ }^{2}$, Aleš Vetešník ${ }^{3}$, Eva Hofmanová ${ }^{4}$ \\ ${ }^{1}$ Department of Nuclear Chemistry, Faculty of Nuclear Sciences and Physical Engineering, \\ Czech Technical University in Prague, Břehová 7, 11519 Prague, Czech Republic \\ e-mail: lucie.baborova@fjfi.cvut.cz \\ ${ }^{2}$ Department of Nuclear Chemistry, Faculty of Nuclear Sciences and Physical Engineering, \\ Czech Technical University in Prague, Břehová 7, 11519 Prague, Czech Republic \\ e-mail: dusan.vopalka@fjfi.cvut.cz \\ ${ }^{3}$ Department of Nuclear Chemistry, Faculty of Nuclear Sciences and Physical Engineering, \\ Czech Technical University in Prague, Břehová 7, 11519 Prague, Czech Republic \\ e-mail: ales.vetesnik@fjfi.cvut.cz \\ ${ }^{4}$ Department of Nuclear Chemistry, Faculty of Nuclear Sciences and Physical Engineering, \\ Czech Technical University in Prague, Břehová 7, 11519 Prague, Czech Republic \\ e-mail: hofmanova.eva@gmail.com \\ ${ }^{4}$ ÚJV Řež, a.s., Fuel Cycle Chemistry Department, Hlavní 130, 25068 Husinec - Řež, Czech Republic \\ Cite as: Baborová, L., Vopálka, D., Vetešník, A., Hofmanová, E., Migration Behaviour of Strontium in Czech \\ Bentonite Clay, J. sustain. dev. energy water environ. syst., 4(3), pp 293-306, 2016, \\ DOI: http://dx.doi.org/10.13044/j.sdewes.2016.04.0023
}

\begin{abstract}
The study deals with sorption and diffusion behaviour of strontium in Czech bentonite $\mathrm{B} 75$. The study is a part of a research on reactive transport of radioactive contaminants in barrier materials of a deep geological repository of radioactive waste in the Czech Republic. Series of sorption and diffusion experiments with $\mathrm{Sr}$ and non-activated $\mathrm{Ca}$ bentonite B75 produced in the Czech Republic were performed in two background solutions $\left(\mathrm{CaCl}_{2}\right.$ and $\left.\mathrm{NaCl}\right)$. On the basis of sorption batch experiments the kinetics of strontium sorption on bentonite was assessed and the sorption isotherms for various experimental conditions were obtained. As a result of performed diffusion experiments the parameters of diffusion (i.e. effective diffusion coefficient $D_{\mathrm{e}}$ and apparent diffusion coefficient $D_{\mathrm{a}}$ ) were determined. The observed discrepancies between sorption characteristics obtained from the sorption and diffusion experiments are discussed.
\end{abstract}

\section{KEYWORDS}

Bentonite, Strontium, Radionuclide migration, Reactive transport, Diffusion experiments, Batch method.

\section{INTRODUCTION}

The aim of the study is sorption and diffusion behaviour of strontium on Czech bentonite clay. Many studies were carried out worldwide to evaluate suitability of bentonite as a backfill and barrier material. Numerous studies performed in last 20 years with the natural Wyoming bentonite (MX-80) brought not only knowledge about the qualities of this type of bentonite but also established a set of laboratory procedures and methods of their evaluation that is being used for the study of clay materials. Batch experiments with $\mathrm{Sr}$ on MX-80 under various conditions accompanied by PHREEQC modelling were carried out by Garrido et al. [1]. Sorption behaviour of Sr and Cs on MX-80 was described by Liang et al. [2] with the use of two-stage Freundlich isotherm. Principles of ion diffusion in compacted bentonite were studied and summarized by

\footnotetext{
* Corresponding author
} 
Eriksen [3] as early as 1982. Diffusion and mobilities of various radionuclides under various redox conditions were under scope of Torstenfelt et al. [4]. Later, Eriksen and Jansson [5] and Eriksen et al. [6] combined sorption batch experiments and diffusion experiments to shed some light on the phenomenon of surface diffusion. Another thorough study of sorption and diffusion properties of bentonite was done by $\mathrm{Yu}$ and Neretnieks [7] and this work was updated by Ochs [8]. Comparison of $K_{\mathrm{d}}$ 's obtained from sorption and diffusion experiments was provided by Brandberg and Skagius [9].

The standardized procedures of sorption and diffusion experiments were also performed for example on Spanish (FEBEX) [10], Slovakian [11], Pakistani [12] or Japanese (Kunipia and Kunigel) [13] bentonites. These studies provided information regarding physical characteristics and sorption behaviour of bentonite and clay minerals of the smectite group, mostly under repository conditions. However, materials from different localities may behave differently due to the variations in their composition. Therefore, each material requires specific studies. Data obtained by sorption and diffusion laboratory and in situ experiments contribute to the understanding of contaminant migration in the environment and also can serve as input data for the predictive models. In some cases [14], data from sorption batch experiments are used in the base documentation for predictive modelling and performance or safety assessment. This simplified approach certainly reduces the time required for the safety data acquisition; however, the accuracy of such data may be questionable. Physico-chemical properties of bentonite material may be altered in compacted state (as in the diffusion experiment) compared to loose state (as in the batch experiment). Therefore, this study shows and compares data obtained for these two types of experiments under various conditions.

\section{Sorption and diffusion properties of $\mathrm{Sr}$}

Together with caesium isotopes, isotope ${ }^{90} \mathrm{Sr}$ belongs to the most abundant fission products and its relatively long half-life $\left(T_{1 / 2}=28.8\right.$ years $)$ ranks it to the group of radionuclides that occur in the spent nuclear fuel after its disposal [15]. Under repository conditions it exists mainly in the form of $\mathrm{Sr}^{2+}$. Owing to it's relatively simple chemistry and chemical similarity with other elements from the group of alkali earth metals, $\mathrm{Sr}$ serves in various studies as an analogue of other critical radionuclides, particularly Ra.

In one of SKB reports, Yu and Neretnieks [7] described basic principles of sorption and diffusion behaviour of various radionuclides in compacted bentonite (MX-80). Sorption experiments with Sr on other types of bentonite were carried out e.g. on Spanish FEBEX bentonite [10], Slovakian [11] or Pakistani bentonite [12]. All of these sources agree that the sorption kinetics of $\mathrm{Sr}$ on clay-type material is fast and equilibrium state is reached within few hours. The sorption of $\mathrm{Sr}$ is usually described as non-specific and reversible and the sorption mechanism is mostly considered to be ion exchange. This is supported by the fact that $\mathrm{Sr}$ sorption is dependent on the ionic strength and the composition of exchangeable complexes. Competitive strength of an ion depends on it's charge and hydrated diameter. Most important competitive ion for $\mathrm{Sr}$ is reported to be $\mathrm{Ca}$ due to it's similar hydrated diameter and the same charge. This may be also illustrated by the fact that the sorption behaviour of $\mathrm{Sr}$ and $\mathrm{Ca}$ was found to be very similar from both qualitative and quantitative points of view [10]. Decreasing trend of Sr sorption with the increasing ionic strength is described in studies of Missana et al. [10] or Ruminin et al. [16]. At higher $\mathrm{pH}$ values (>8) mechanism of surface complexation may be also of importance. Both Cole et al. [17] and Carrol et al. [18] studied thoroughly sorption process of $\mathrm{Sr}$ in loose or compacted clay materials with the use of EXAFS method and mathematical modelling and in their works they describe Sr pore water and surface 
speciation in detail. The results of both authors indicate that adsorption of $\mathrm{Sr}$ to clay surfaces occurs as weak outer sphere bonding (single coordination shell of the ion interacts with the mineral surface). Cole et al. [17] also showed that minor occurrence of an aquo-carbonate species $\mathrm{SrCO}_{3}$ (aq) significantly increases the total adsorption affinity of $\mathrm{Sr}$ for the clay surface above $\mathrm{pH}$ 8.5. In the study of Eriksen et al. [6] sorption of Sr on bentonite was also found to be $\mathrm{pH}$ dependent and the highest uptake was observed at $\mathrm{pH}$ 8.5. According to Liang et al. [2], several reasons may be responsible for this behaviour, e.g. enhanced negative surface charge of bentonite clay minerals; enhanced dissolution of bentonite; precipitation of $\mathrm{Sr}$ as $\mathrm{Sr}(\mathrm{OH})_{2}$. It was also found that $\mathrm{pH}$ dependence increases with increasing initial concentration of $\mathrm{Sr}$ [1]. On the other hand, Spanish researchers [10] showed that sorption of $\mathrm{Sr}$ in concentration range from $10^{-9}$ to $10^{-4} \mathrm{~mol} / \mathrm{L}$ is more dependent on ionic strength than on $\mathrm{pH}$. Precipitation or co-precipitation of $\mathrm{Sr}$ with carbonates, sulphates or hydroxides may influence Sr removal from the liquid phase, especially at higher $\mathrm{pH}$ values $(>8)$ or at higher concentrations of these compounds in the system.

\section{MATERIALS AND METHODS}

Two types of methodologies were performed within the frame of this work with the aim to determine diffusion parameters of $\mathrm{Sr}$ in the Czech bentonite B75 and to compare distribution coefficients obtained from sorption batch experiments and diffusion experiments with compacted bentonite.

\section{Bentonite}

The material used was commercial non-activated bentonite 75 (B75) which originates from the Rokle deposit (Cenozoic neovolcanic area, NW Bohemia, Czech Republic). This material belongs to the natural bentonite product group and no additives or modifications applications were declared [19]. Detailed mineralogical and chemical characterization of bentonite B75 was performed in the Czech Republic [20]. According to the analyses, B75 contained $75.5 \%$ of montmorillonite and CEC was $56.8 \mathrm{meq} / 100 \mathrm{~g}$. The analyses indicated that originally $\mathrm{Ca} / \mathrm{Mg}$ bentonite was probably contaminated during the processing with the activation reagent which is being used to transform other types of bentonites into Na-form on the same production line, which is illustrated by distribution of major cations summarized in Table 1.

Table 1. Cation Exchange Capacity (CEC) and distribution of major exchangeable cations in bentonite B75 [meq/100g] determined by Cu-trien method [20]

\begin{tabular}{cc}
\hline & {$[\mathrm{meq} / 100 \mathrm{~g}]$} \\
\hline $\mathrm{CEC}$ & $56.8 \pm 1$ \\
$\mathrm{Ca}$ & $2.0 \pm 0.7$ \\
$\mathrm{Mg}$ & $26.4 \pm 0.7$ \\
$\mathrm{Na}$ & $36.9 \pm 0.4$ \\
$\mathrm{~K}$ & $3.6 \pm 0.1$ \\
\hline
\end{tabular}

\section{Description of reactive diffusive transport}

In materials with low hydraulic conductivity, such as in clay materials, the migration of radionuclides is mainly controlled by diffusion. Diffusive transport in saturated homogenous and isotropic system is described by Fick's diffusion laws, solutions of which for simple initial and boundary conditions are used for the evaluation of diffusion 
experiments. These approaches, which are based on the solution of the 1D diffusion eq. (1), are collected e.g. in the works of Yu and Neretnieks [7] or Shackelford and Moore [21]. Diffusion of radionuclides through the layer of compacted bentonite is influenced by both physical (porosity $\varepsilon$, geometric factor $G$ ) and chemical parameters of kinetic and equilibrium models describing the interaction of studied species with the solid phase. The dependences of diffusion parameters, namely effective diffusion coefficient $D_{\mathrm{e}}$ and apparent diffusion coefficient $D_{\mathrm{a}}$, on physical and chemical parameters were for the description of sorption by the linear equilibrium model expressed by eq. (2) and (3):

$$
\begin{gathered}
\frac{d C}{d t}=D_{\mathrm{p}} \frac{d^{2} C}{d x^{2}}-\frac{\rho_{\mathrm{d}}}{\varepsilon} \frac{d q}{d t} \\
D_{\mathrm{e}}=\varepsilon \times D_{\mathrm{p}}=\varepsilon \times G \times D_{\mathrm{w}} \\
D_{\mathrm{a}}=\frac{D_{\mathrm{e}}}{\varepsilon+\rho_{\mathrm{d}} \times K_{\mathrm{d}}}
\end{gathered}
$$

where: $C$ is concentration in the liquid phase, $q$ is concentration in the solid phase, $D_{\mathrm{w}}$ is reference diffusivity in water, $D_{\mathrm{p}}$ is pore diffusion coefficient, $x$ is longitudinal coordinate, $\rho_{\mathrm{d}}$ is dry density, $\varepsilon$ is porosity, $G$ is geometric factor, $K_{\mathrm{d}}$ is distribution coefficient.

\section{Sorption experiments}

The standard batch method [22] was used for the study of Sr sorption kinetics and equilibrium characteristics. The range of solid-to-liquid ratio $(\mathrm{m} / \mathrm{V})$ varied from 0.005 to $0.2 \mathrm{~g} / \mathrm{mL}$ (Figure 1). With the aim to assess the difference between distribution coefficients $K_{\mathrm{d}}$ obtained from the sorption experiments with equilibrated and non-equilibrated bentonite samples, equilibrated (presaturated) bentonite was prepared. For that purpose, the bentonite samples (weighed with the correction on actual water content) were contacted with background electrolyte for $3 \times 24$ hours before the start of a batch experiment with Sr.

The experiments were performed with two values of $\mathrm{Sr}$ concentration, $10^{-3} \mathrm{~mol} / \mathrm{L}$ and $10^{-5} \mathrm{~mol} / \mathrm{L}$ of $\mathrm{SrCl}_{2}$ spiked with radioactive tracer ${ }^{85} \mathrm{Sr}\left(T_{1 / 2}=64.8 \mathrm{~d}\right.$, produced by LACOMED company). As background solutions were used either $0.033 \mathrm{~mol} / \mathrm{L} \mathrm{CaCl}_{2}$ or $0.1 \mathrm{~mol} / \mathrm{L} \mathrm{NaCl}$. The ionic strength of both solutions was $0.1 \mathrm{~mol} / \mathrm{L}$. The initial $\mathrm{pH}$ was in the neutral range. All experiments were carried out under laboratory temperature. Based on the kinetic experiments, which ranged from 15 minutes up to 19 days, contact time for equilibrium characteristics was set to 3 days.

At the start of the experiment, the bentonite samples were contacted with $6 \mathrm{~mL}$ of solution containing background electrolyte and $\mathrm{SrCl}_{2}$ in desired concentration spiked with ${ }^{85} \mathrm{Sr}$. Vials were placed into the horizontal shaker (Yellowline RS10 basic, $120 \mathrm{rpm}$ ). After the desired contact time they were centrifuged (MPW-350R, $10 \mathrm{~min}, 966 \mathrm{~g}$ ), $2 \mathrm{~mL}$ of supernatant were extracted into measuring vials and ${ }^{85} \mathrm{Sr}$ activity was measured in the well-type $\mathrm{NaI}(\mathrm{Tl})$ detector (Tesla, $\eta \approx 24 \%$ ) with single-channel analyser (Tema JKA300 RS232). After the termination of experiments, $\mathrm{pH}$ was measured to assess the influence of the contact of solution with various amounts of bentonite.

For calculations of $K_{\mathrm{d}}[\mathrm{L} / \mathrm{kg}]$ usual eq. (4) was used [23]:

$$
K_{\mathrm{d}}=\frac{q}{C}
$$


where: $q$ is concentration of $\operatorname{Sr}$ sorbed on the solid phase in equilibrium $\left(q=\frac{\left(C_{0}-C\right) \times V}{m}\right)$, $C_{0}$ is initial concentration in the liquid phase, $C$ is concentration in the liquid phase in equilibrium, $V$ is volume of the liquid phase, $m$ is mass of the solid phase.

Overall distribution coefficient $K_{\mathrm{d}}$ of each experiment was determined from the slope of the linear regression fitted to the data expressing the relation between $q[\mathrm{~mol} / \mathrm{kg}]$ and $C$ $[\mathrm{mol} / \mathrm{L}]$.

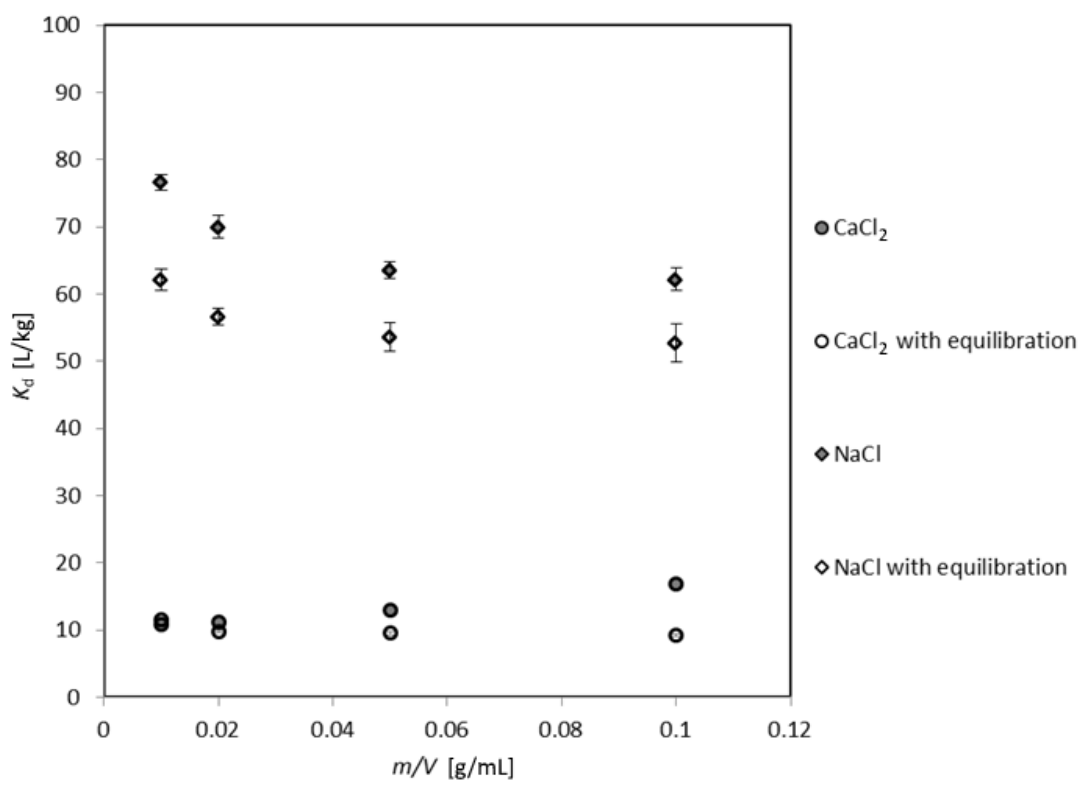

Figure 1. Distribution coefficient $K_{\mathrm{d}}(4)$ as a function of $m / V[\mathrm{~g} / \mathrm{mL}]$

\section{Diffusion experiments}

Diffusion experiments were carried out in a diffusion cell (the set-up is described in [20]). The amount of bentonite, weighed according to the chosen dry density $(1,300$ or $1,600 \mathrm{~kg} / \mathrm{m}^{3}$ ) and actual water content, was pressed into the steel sample holder $(d=30 \mathrm{~mm})$ by a simple manual press. Diffusion cells with bentonite plugs of two lengths $(15 \mathrm{~mm}$ and $5 \mathrm{~mm})$ were prepared and reservoirs of the volume of $190 \mathrm{~mL}$ were used. Firstly, the compacted bentonite was saturated with the studied background solution, i.e. $0.033 \mathrm{~mol} / \mathrm{L} \mathrm{CaCl}_{2}$ or $0.1 \mathrm{~mol} / \mathrm{L} \mathrm{NaCl}$, in the vacuum chamber for two weeks. The direction of saturation was changed at least once. This step may also partly remove the concentration excess of soluble carbonates, which are present in B75 as a contamination from the activation procedure.

At the start of each experiment, the outlet reservoir was filled with $160 \mathrm{~mL}$ of the fresh solution of background electrolyte and in the inlet reservoir was in addition injected solution of $\mathrm{SrCl}_{2}$ in the concentration of $10^{-3} \mathrm{~mol} / \mathrm{L}$ spiked with ${ }^{85} \mathrm{Sr}$. The samples of inlet and outlet solutions were withdrawn in regular intervals until the experiment was terminated and measured in the same way as in sorption experiments. After the determination of ${ }^{85} \mathrm{Sr}$ activity the samples were returned into the reservoirs. At the experiment termination, the bentonite plug was cut into the thin slices of 0.5 or $1 \mathrm{~mm}$. Each slice was placed into the measuring vial, weighed, dried in the air dryer and then weighed again to determine the water content. Before ${ }^{85} \mathrm{Sr}$ activity measurement, $3 \mathrm{~mL}$ of distilled water were added to each sample to maintain homogeneous geometry. As a result, concentration profile of $\mathrm{Sr}$ in the bentonite plug was obtained.

Diffusion experiments lasted from 21 to 42 days. With the aim to reduce the duration of the diffusion experiments, they were not led to stationary state. Therefore, no standard 
evaluation method (e.g. "time-lag" method published e.g. by Shackelford [24]) could be used for the determination of both effective diffusion coefficient $D_{\mathrm{e}}$ and apparent diffusion coefficient $D_{\mathrm{a}}$. An original method was used, in which diffusion coefficients were obtained by simultaneous fitting of the concentration profile curves and the time development of concentrations in both reservoirs with an extension of the code prepared in our laboratory [25], which enables to take into account common conditions of through-diffusion experiments (non-constant concentration in working reservoirs during the experiment and the presence of filters). The code was prepared in the GoldSim environment [26] and uses an implementation of Box's method [27] for the optimization of selected parameters of the model. The values of $K_{\mathrm{d}}$ and geometric factor $G$ were optimized, with fixed values of filter parameters (length $l_{\mathrm{f}}=0.8 \mathrm{~mm}$, bulk density $\rho_{\mathrm{f}}=3,000 \mathrm{~kg} / \mathrm{m}^{3}$, porosity $\varepsilon_{\mathrm{f}}=0.33$ and geometric factor $\left.G_{\mathrm{f}}=0.045\right)$ and with the value of reference diffusivity $D_{\mathrm{w}}=1.58 \times 10^{-9} \mathrm{~m}^{2} / \mathrm{s}$ [28]. Bentonite B75 specific density $\rho_{\mathrm{s}}$ was $2,772 \mathrm{~kg} / \mathrm{m}^{3}$ [20] and porosity $\varepsilon$ was calculated for each sample from the value of weighted dry mass of bentonite.

\section{RESULTS AND DISCUSSION}

\section{Sorption experiments}

It was confirmed that $\mathrm{Sr}^{2+}$ sorption kinetic on this type of material is very fast, over $90 \%$ of the total sorptives was adsorbed within one hour. On the scale of several days some trend in the change of sorption was observed, although the change was below 5\% level during 24 hours, which is recommended as a borderline of equilibrium state [22]. Based on this result, contact time for equilibrium sorption experiments was set to 3 days. The sorption kinetics of $\mathrm{Sr}$ was faster in the $\mathrm{NaCl}$ environment compared to the $\mathrm{CaCl}_{2}$ environment. In this study, initial $\mathrm{pH}$ was naturally buffered from the value of about 6.8 up to 7.5 in the case of $\mathrm{CaCl}_{2}$ solution and up to 8.4 in the case of $\mathrm{NaCl}$ solution respectively, depending also on $m / V$ ratio. We assume that ion exchange was the dominant sorption mechanism, even though precipitation with carbonates, especially in $\mathrm{NaCl}$ background solution, may have contributed to $\mathrm{Sr}$ removal from the liquid phase.

Figure 1 shows the difference between distribution coefficients $K_{\mathrm{d}}$ obtained from experiments with equilibrated and non-equilibrated bentonite samples. In the case of $\mathrm{CaCl}_{2}$ solution the decrease in $K_{\mathrm{d}}$ value was of $11.7 \%$ and of $18.7 \%$ in the case of $\mathrm{NaCl}$ solution. Furthermore, after equilibration the dependence of $K_{\mathrm{d}}$ on the $\mathrm{m} / \mathrm{V}$ ratio decreased, especially in the $\mathrm{CaCl}_{2}$ solution. It supports the hypothesis that bentonite $\mathrm{B} 75$ had been contaminated with activation reagent and soluble carbonates contribute to $\mathrm{Sr}$ removal from the liquid phase. Many authors report that precipitation or co-precipitation of $\mathrm{Sr}$ with carbonates, sulphates or hydroxides may influence $\mathrm{Sr}$ removal from the liquid phase, especially at higher $\mathrm{pH}$ values $(>8)$ or at higher concentrations of these compounds in the system. Cole et al. [17] stated that $K_{\mathrm{d}}$ of $\mathrm{SrCO}_{3}$ for clay material is $60 \times$ higher than $K_{\mathrm{d}}$ for $\mathrm{Sr}^{2+}$ and that its sorption is reversible.

As showed in Figure 2, for sorption of $\mathrm{Sr}$ in the $\mathrm{NaCl}$ environment the linear isotherm (4) is applicable. The slope of the linear regression represents the overall $K_{d}$ of the experiment. Values of $K_{\mathrm{d}}$ were generally higher for the experiment where $\mathrm{NaCl}$ background solution was used (see Figure 1). This could be accounted to the effect of weaker competitive strength of Na relative to $\mathrm{Ca}$ [1]. Some data, especially from $\mathrm{CaCl}_{2}$ solution, show a rather non-linear trend. This may be caused by relatively high concentration of $\mathrm{Sr}$ combined with competition with $\mathrm{Ca}$ ion. According to Liang et al. [2], Sr concentration of $10^{-3} \mathrm{~mol} / \mathrm{L}$ may be high enough to result in the curved shape of the isotherm. 


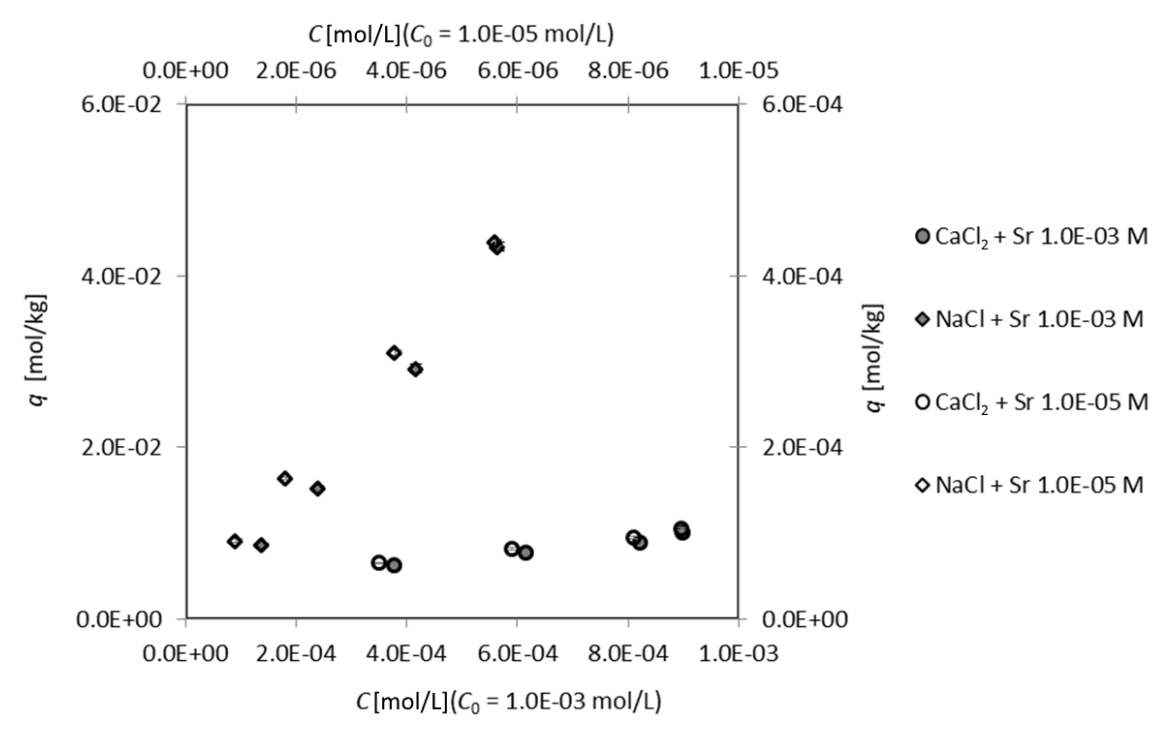

Figure 2. Sorption isotherms of $\mathrm{Sr}$ on bentonite B75 for four types of initial solution

Regarding the linearity of Sr sorption, sources are not absolutely unambiguous. Some authors, e.g. [10], consider the use of $K_{\mathrm{d}}$ for Sr sorption on bentonite and similar materials to be sufficient. Freundlich isotherm for Sr sorption on bentonite was used by Liang et al. [2] and Tsai et al. [29]. Galambos et al. [11] used Langmuir isotherm for the evaluation of Sr sorption on Slovak bentonite. The main advantage of the use of $K_{\mathrm{d}}$ is that it may be relatively easily determined and compared. On the other hand, the disadvantage is it's exclusive relevance for given conditions, resulting in problematic transfer to real conditions. $K_{\mathrm{d}}$ dependence on experimental conditions causes relatively wide variability of values found in literature. For example, sorption and diffusion behaviour of various radionuclides including $\mathrm{Sr}$ in the granitic environment is summarized in the SKB report [30] and the authors recommend $K_{\mathrm{d}}$ value to be $10 \mathrm{~L} / \mathrm{kg}$ with the uncertainty interval from 5 to $50 \mathrm{~L} / \mathrm{kg}$.

\section{Diffusion experiments}

The graphs in Figure 3 show the relative change of concentration in the inlet reservoirs in time of the experiment duration and concentration profiles in the bentonite plugs after the experiment termination. From the qualitative evaluation of these experiments it is possible to draw following conclusions.

The linear course of concentration profiles in the bentonite layer suggests that the experiments performed in diffusion cells of $5 \mathrm{~mm}$ in length approached stationary state. However, the comparison of in-flow to and out-flow from the bentonite layer showed that these are not equivalent and therefore the assumption that the stationary state is reached is not true. In the cells with length of $15 \mathrm{~mm}$ reaching stationary state would last several more weeks or months [31].

It is showed that the course of the diffusion experiments (especially of those which lasted 21 days) differs significantly for different background solutions but it does not differ much in dependence of dry density. This can be noted even for the diffusion parameters summarized in Table 2, even though diffusion parameters exhibit relatively large variance. $D_{\mathrm{e}}$ and $D_{\mathrm{a}}$ values should, according to $\mathrm{Yu}$ and Neretnieks [7], decrease with increasing dry density. Others [3], however, did not observe significant influence of dry density and homogeneity of material on diffusion parameters. Here, the difference is expressed mainly in the amount of Sr sorbed in the solid phase. When the compaction is higher, the more sorbent is available to take up higher amount of $\mathrm{Sr}$ which is in agreement 
with theoretical assumption. The ratio of the sorbed amount in the two environments is, however, in contrast to the results of sorption experiments, where higher sorption of $\mathrm{Sr}$ was observed in the $\mathrm{NaCl}$ environment (compare Table 2 and Table 3). Explanation of differences between values of $K_{\mathrm{d}}$ determined from diffusion and sorption experiments as well as explanation of differences in migration behaviour of $\mathrm{Ca}$ and $\mathrm{Na}$ bentonite are discussed by many authors. In studies of Eriksen et al. [6] and Eriksen and Jansson [5], distribution coefficients $K_{\mathrm{d}}$ found in sorption and diffusion experiments were similar and the assumption that $K_{\mathrm{d}}$ would be lower for diffusion experiment was not proved. The difference between $K_{\mathrm{d}}$ obtained from sorption and diffusion experiments was reported by Missana et al. [10] and Van Loon et al. [32] but, according to these authors, the uncertainty was within the range and was accounted to the difference in methodology of experiments. Another authors, e.g. Yu and Neretnieks [7] and Brandberg and Skagius [9], observed the differences between $K_{\mathrm{d}}$ values obtained from sorption and diffusion experiments. These differences may be accounted to different preference of ion exchange in loose and compacted bentonite. While in the case of loose bentonite, divalent ions and ions with larger diameter are competitively stronger, it is just opposite in the case of compacted bentonite. It may be due to two reasons:

- The interlayer spaces are not completely opened in compacted bentonite and therefore not all of the sorption places are available;

- Ions in the compacted bentonite move without (or partly without) their hydration shell.
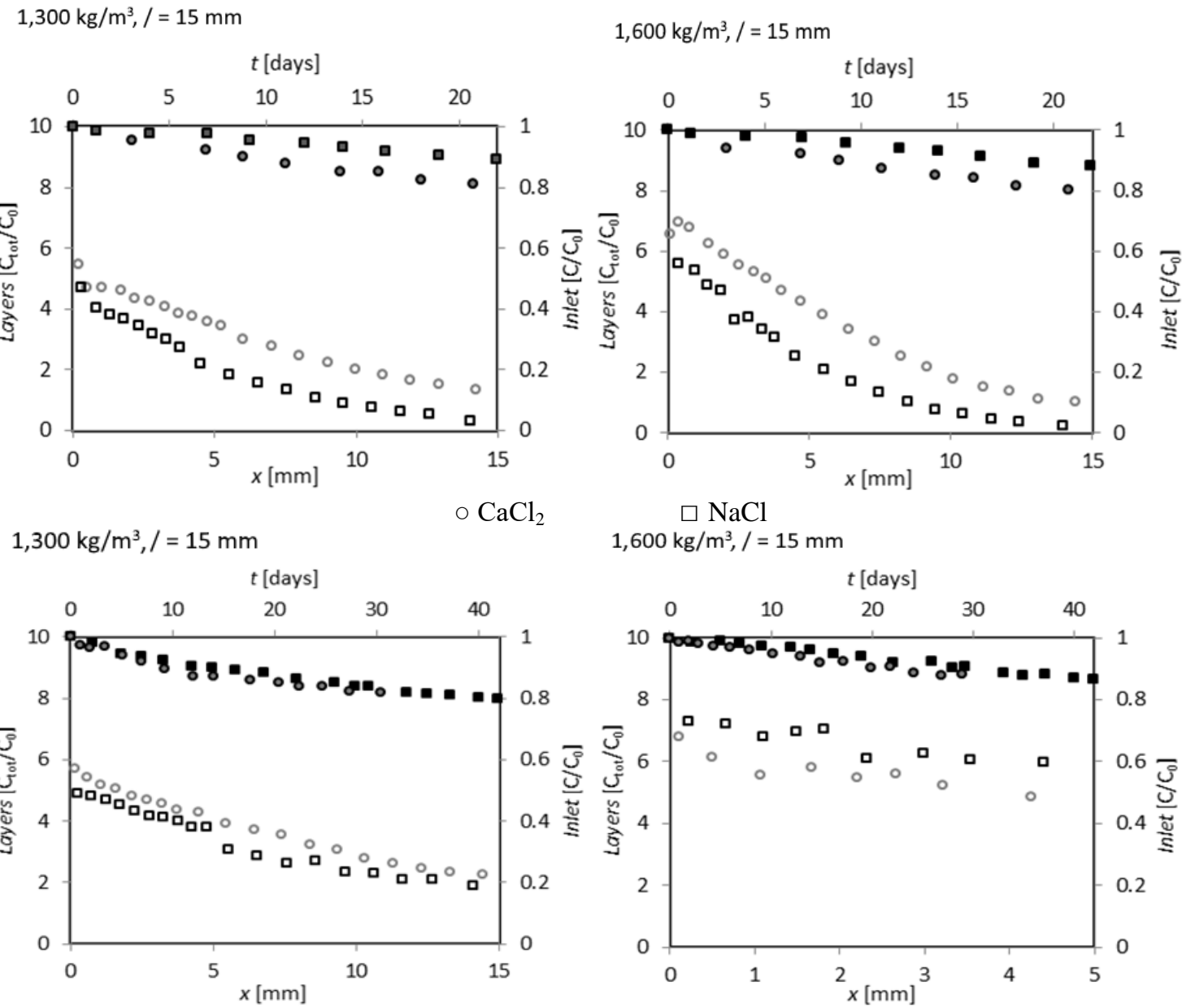

Figure 3. Data obtained from diffusion experiments with $\mathrm{Sr}$ and bentonite $\mathrm{B} 75$ compacted to $1,300 \mathrm{~kg} / \mathrm{m}^{3}$ (left) and $1,600 \mathrm{~kg} / \mathrm{m}^{3}$ (right) for two types of background solution $\left(\mathrm{CaCl}_{2}\right.$ and $\left.\mathrm{NaCl}\right)$ 
Some studies [14], where the use of data from sorption experiments is applied, are defended, e.g. in previous study [33] or by Ochs et al. [34], who claim that distribution coefficients are applicable for the conditions of compacted material, when appropriate $\mathrm{m} / \mathrm{V}$ ratio and pore water chemistry is considered and the data are extrapolated for these conditions.

Table 2. Summary of diffusion parameters of Sr on bentonite B75

\begin{tabular}{ccccccccc}
\hline $\begin{array}{c}\text { Background } \\
\text { solution }\end{array}$ & $\begin{array}{c}\text { Length of } \\
\text { cell }[\mathrm{mm}]\end{array}$ & $\begin{array}{c}\text { Contact } \\
\text { time } \\
{[\text { days] }}\end{array}$ & $\begin{array}{c}\rho_{\mathrm{d}} \\
{\left[\mathrm{kg} / \mathrm{m}^{3}\right]}\end{array}$ & $\varepsilon[-]$ & $\begin{array}{c}K_{\mathrm{d}} \\
{[\mathrm{L} / \mathrm{kg}]}\end{array}$ & $\begin{array}{c}G[-] \\
\times\end{array}$ & $\begin{array}{c}D_{\mathrm{a}} \\
\times 0^{11} \\
{\left[\mathrm{~m}^{2} / \mathrm{s}\right]}\end{array}$ & $\begin{array}{c}D_{\mathrm{e}} \\
\times 10^{10} \\
{\left[\mathrm{~m}^{2} / \mathrm{s}\right]}\end{array}$ \\
\hline & 15 & 29 & 1,604 & 0.422 & 8.3 & 0.410 & 2.25 & 2.74 \\
$0.033 \mathrm{M} \mathrm{CaCl}_{2}$ & 15 & 30 & 1,604 & 0.421 & 6.9 & 0.466 & 3.04 & 3.11 \\
& 15 & 30 & 1,314 & 0.526 & 7.5 & 0.679 & 5.77 & 5.65 \\
& 15 & 21 & 1,296 & 0.523 & 6.7 & 0.501 & 4.97 & 4.14 \\
& 15 & 21 & 1,596 & 0.414 & 8.2 & 0.542 & 3.74 & 3.55 \\
\hline $0.1 \mathrm{M} \mathrm{NaCl}$ & 15 & 42 & 1,300 & 0.531 & 5.8 & 0.362 & 3.63 & 3.04 \\
& 5 & 42 & 1,596 & 0.424 & 9.3 & 0.800 & 8.82 & 5.37 \\
& 15 & 21 & 1,300 & 0.531 & 4.1 & 0.104 & 1.44 & 0.877 \\
& 15 & 21 & 1,600 & 0.423 & 4.6 & 0.126 & 1.27 & 0.845 \\
\hline
\end{tabular}

Table 3. Summary of experimental conditions and distribution coefficients of $\mathrm{Sr}$ on bentonite B75

\begin{tabular}{ccc}
\hline Sr initial concentration $[\mathrm{mol} / \mathrm{L}]$ & Background solution & $K_{\mathrm{d}}[\mathrm{L} / \mathrm{kg}]$ \\
\hline $1.0 \mathrm{E}-03$ & $0.033 \mathrm{M} \mathrm{CaCl}_{2}$ & $11.6 \pm 0.8$ \\
$1.0 \mathrm{E}-03$ & $0.033 \mathrm{M} \mathrm{CaCl}_{2}$ with equilibration & $10.3 \pm 0.6$ \\
$1.0 \mathrm{E}-05$ & $0.033 \mathrm{M} \mathrm{CaCl}_{2}$ & $12.5 \pm 1.0$ \\
$1.0 \mathrm{E}-03$ & $0.1 \mathrm{M} \mathrm{NaCl}$ & $72.8 \pm 2.8$ \\
$1.0 \mathrm{E}-03$ & $0.1 \mathrm{M} \mathrm{NaCl}$ with equilibration & $59.2 \pm 2.0$ \\
$1.0 \mathrm{E}-05$ & $0.1 \mathrm{M} \mathrm{NaCl}$ & $80.3 \pm 2.4$ \\
\hline
\end{tabular}

Contact time was 21 days (top) and 30 or 42 days (bottom). Solid points represent $\mathrm{Sr}$ concentration decrease in inlet reservoirs during the experiment duration. Open points represent Sr concentration profile in the bentonite plug after the experiment termination.

From the different speed of concentration decrease in the inlet reservoirs of the experiments it can be seen that for both values of compaction the diffusive transport was slower in the $\mathrm{NaCl}$ environment compared to $\mathrm{CaCl}_{2}$ environment (see Figure 3). It may be caused by higher sorption in the $\mathrm{CaCl}_{2}$ environment under the conditions of compacted bentonite and/or higher diffusive resistance of the bentonite in the $\mathrm{NaCl}$ environment. The first conclusion is supported by the higher $\mathrm{Sr}$ concentration in the bentonite layer in the $\mathrm{CaCl}_{2}$ environment. Sorption generally enhances diffusive transport because it lowers the concentration in the liquid phase and thus enhances concentration gradient. The second conclusion is also in agreement with the recent state of knowledge. Different behaviour of $\mathrm{Ca}$ and $\mathrm{Na}$ bentonite lies above all in their different 
physical behaviour, which is quite well described in literature, e.g. by Katsumi et al. [35] or Montes-H. et al. [36]. In Na bentonites are observed higher swelling pressures, which is accompanied by the decrease in the volume of wider (intergranular) pores in ratio to smaller (intragranular/interlayer) pores. The first effect should lead to decrease in the value of $K_{\mathrm{d}}$ in $\mathrm{Na}$ compared to Ca environment, which may be confirmed by the data presented here. The second effect should lead to decrease in the value of $D_{\mathrm{e}}$ in $\mathrm{Na}$ bentonite. This is confirmed by Choi and Oscarsson [37] who observed 2-6× lower $D_{\mathrm{e}}$ in Na bentonite compared to $\mathrm{Ca}$ bentonite. They also compared porosities of these two types of bentonite by $\mathrm{Hg}$ porosimetry measurement. Although the values of diffusion coefficients presented here show rather large variance, the observed breakthrough times of $\mathrm{Sr}$ through bentonite plug were generally longer in $\mathrm{NaCl}$ environment compared to $\mathrm{CaCl}_{2}$ environment.

Values of $D_{\mathrm{e}}$ for $\mathrm{Sr}$ on compacted bentonite usually range in the order of $10^{-10} \mathrm{~m}^{2} / \mathrm{s}$ and $D_{\mathrm{a}}$ in the order of $10^{-11} \mathrm{~m}^{2} / \mathrm{s}$, as reviewed in many reports and articles. All of the values summarized in the Table 3 are within this range. In general, it can be concluded that diffusion parameters $\left(K_{\mathrm{d}}, G, D_{\mathrm{a}}, D_{\mathrm{e}}\right)$ are higher in the $\mathrm{CaCl}_{2}$ environment compared to $\mathrm{NaCl}$ environment. This is related to the above described differences between $\mathrm{Ca}$ and $\mathrm{Na}$ bentonite. This is also supported by the difference in the relative change in concentration decrease in inlet reservoirs. The values of diffusion coefficients, however, exhibit relatively large variance and their uncertainty may be relatively large (>10\%). It is given by heterogeneity of bentonite material, uncertainties of experimental character and uncertainties related to newly established optimization program. Experimental set up may also influence values of diffusion parameters and their associated uncertainties. Aldaba et al. [38] for example compared diffusion coefficients obtained from evaluation of various types of diffusion experiments of $\mathrm{Sr}$ and Spanish soil samples, e.g. using half-cell or planar source method, and it was found out that the planar source method underestimates the resulting values of diffusion coefficients.

\section{CONCLUSION}

Sorption and diffusion experiments were performed to investigate sorption and diffusion of $\mathrm{Sr}$ on Czech bentonite B75 under various conditions. Sorption kinetics, sorption isotherms and diffusion parameters were assessed and compared for two types of background solutions. It was confirmed that the sorption of $\mathrm{Sr}$ on bentonite is fast which indicates that the main mechanism of sorption is ion exchange. Diffusion of cationic species through the porous material is influenced by their interaction with the charged surface of the material and by the physical properties of the material. $K_{\mathrm{d}}$ values obtained from sorption and diffusion experiments were compared and it was shown that there may occur significant discrepancies between $K_{\mathrm{d}}$ values obtained from these two types of experiments. Whereas $K_{\mathrm{d}}$ values of $\mathrm{Sr}$ obtained from sorption experiments in $\mathrm{NaCl}$ environment were approximately 7 times higher compared to $\mathrm{CaCl}_{2}$ environment, this ratio was opposite in diffusion experiments. This was accounted to different physical conditions of bentonite during these two types of experiments. Moreover, the diffusion of $\mathrm{Sr}$ was slower in $\mathrm{NaCl}$ environment than in $\mathrm{CaCl}_{2}$ environment, which may be explained by higher tortuosity of bentonite with dominating $\mathrm{Na}$ ion. Prepared original method of evaluation of diffusion experiments which are not led to the stationary state does not require long duration of experiments, which is very valuable in terms of minimization of time necessary for migration data acquisition. Development of experimental and modelling methodologies is an important part of scientific support for the future repository. This work contributes to the understanding of transport processes in bentonite barrier of geological repository with respect to the conditions of Czech concept and helps 
to evaluate local materials. Development of experimental and modelling methodologies is also an important part of scientific support for future geological repository. Further work is needed to investigate the influence of other factors, such as bentonite and related pore water composition and their alterations and combinations under real conditions, on the sorption and diffusion processes.

\section{ACKNOWLEDGEMENT}

This work is partially a result of Radioactive Waste Repository Authority project „Research support for Safety Evaluation of Deep Geological Repository“ and partially a result of grant No. SGS13/224/OHK4/3T/14 provided by the Grant Agency of the Czech Technical University in Prague.

\section{NOMENCLATURE}

B75 Czech bentonite 75 produced by Keramost company

C solute concentration in the liquid phase

$C_{0} \quad$ solute initial concentration in the liquid phase

$[\mathrm{mol} / \mathrm{L}]$

solute concentration in the layer of bentonite plug

$C_{\text {tot }} \quad$ (in both liquid and solid phase) after the experiment termination

CEC cation exchange capacity

$D_{\mathrm{a}} \quad$ apparent diffusion coefficient

$D_{\text {e }} \quad$ effective diffusion coefficient

$D_{\mathrm{p}} \quad$ pore diffusion coefficient

$D_{\mathrm{w}} \quad$ reference diffusivity in water

$G \quad$ geometric factor

$G_{\mathrm{f}} \quad$ filter geometric factor

$K_{\mathrm{d}} \quad$ distribution coefficient

$l \quad$ length of bentonite plug

$l_{\mathrm{f}} \quad$ length of filter

$m$ mass

$m / V \quad$ solid-to-liquid ratio

MX-80 natural Wyoming bentonite

$q \quad$ solute concentration in the solid phase

$t \quad$ contact time

$T_{1 / 2} \quad$ half-life of radioactive decay

$V \quad$ volume

$x \quad$ longitudinal coordinate
[mol/L]

$[\mathrm{mol} / \mathrm{L}]$

[meq/100 g]

$\left[\mathrm{m}^{2} / \mathrm{s}\right]$

$\left[\mathrm{m}^{2} / \mathrm{s}\right]$

$\left[\mathrm{m}^{2} / \mathrm{s}\right]$

$\left[\mathrm{m}^{2} / \mathrm{s}\right]$

$[-]$

$[-]$

$[\mathrm{L} / \mathrm{kg}]$

[mm]

[mm]

$[\mathrm{g}, \mathrm{kg}]$

[g/mL, $\mathrm{kg} / \mathrm{L}]$

$[\mathrm{mol} / \mathrm{kg}]$

[days]

[days, years]

[mL, L]

[m]

\section{Greek letters}

$\begin{array}{llc}\varepsilon & \text { bentonite porosity } & {[-]} \\ \varepsilon_{\mathrm{f}} & \text { filter porosity } & {[-]} \\ \eta & \text { efficiency of gama activity measurement } & {[\%]} \\ \rho_{\mathrm{d}} & \text { bentonite bulk density } & {\left[\mathrm{kg} / \mathrm{m}^{3}\right]} \\ \rho_{\mathrm{f}} & \text { filter bulk density } & {\left[\mathrm{kg} / \mathrm{m}^{3}\right]} \\ \rho_{\mathrm{s}} & \text { bentonite specific density } & {\left[\mathrm{kg} / \mathrm{m}^{3}\right]}\end{array}$

\section{REFERENCES}

1. Garrido, V., et al., Sorption Mechanism of Sr(1l) in Natural Bentonite, Mineralogical Magazine, Vol. 62A, pp 502-503, 1998, http://dx.doi.org/10.1180/minmag.1998.62A.1.266 
2. Liang, T.-J., Hsu, C.-N. and Liou, D.-C., Modified Freundlich Sorption of Cesium and Strontium on Wyoming Bentonite, Applied Radiation and Isotopes, Vol. 44, No. 9, pp 1205-1208, 1992, http://dx.doi.org/10.1016/0969-8043(93)90065-I

3. Eriksen, T. E., Ion Diffusion in Compacted Sodium and Calcium Bentonites, SKB Technical Report TR-81-12, 11 p, 1982.

4. Torstenfelt, B., Allard, B., Andersson, K., Kipatsí, H., Eliasson, L., Olofsson, U. and Persson, H., Radionuclide Diffusion and Mobilites in Compacted Bentonite, SKBF KBS Technical Report 83-34, 23 p, 1983.

5. Eriksen, T. and Jansson, M., Diffusion of I-, Cs+ and Sr2+ in Compacted Bentonite - Anion Exclusion and Surface Diffusion, SKB Technical Report TR-96-16, 20 p, 1996.

6. Eriksen, T. E., Jansson, M. and Molera, M., Sorption Effects on Cation Diffusion in Compacted Bentonite, Engineering Geology, Vol. 54, No. 1-2, pp 231-236, 1999 , http://dx.doi.org/10.1016/S0013-7952(99)00078-2

7. Yu, J-W. and Neretnieks, I., Diffusion and Sorption Properties of Radionuclides in Compacted Bentonite, SKB Technical Report TR-97-12, 98 p, 1997.

8. Ochs, M., Review of a Report on Diffusion and Sorption Properties of Radionuclides in Compacted Bentonite, SKB Technical Report 97-15, 31 p, 1997.

9. Brandberg, F. and Skagius, K., Porosity, Sorption and Diffusivity Data for the SKB 91 Study, SKB Technical Report TR-91-16, 34 p, 1991.

10. Missana, T. and Garcia-Gutierrez, M., Adsorption of Bivalent Ions (Ca(II), Sr(II) and Co(II)) onto FEBEX Bentonite, Physics and Chemistry of the Earth, Vol. 32, No. 8-14, pp 559-567, 2007.

11. Galambos, M., Kufcakova, J. and Rajec, P., Sorption of Strontium on Slovak Bentonites, Journal of Radioanalytical and Nuclear Chemistry, Vol. 281, No. 3, pp 347-357, 2009, http://dx.doi.org/10.1007/s10967-009-0017-7

12. Khan, S. A., Riaz-ur, R. and Khan, M. A., Sorption of Strontium on Bentonite, Waste Management, Vol. 15, No. 8, pp 641-650, 1995, http://dx.doi.org/10.1016/0956-053X(96)00049-9

13. Ochs, M., Lothenbach, B., Wanner, H., Sato, H. and Yui, M., An Integrated Sorption-diffusion Model for the Calculation of Consistent Distribution and Diffusion Coefficients in Compacted Bentonite, Journal of Contaminant Hydrology, Vol. 47, No. 2-4, pp 283-296, 2001, http://dx.doi.org/10.1016/S0169-7722(00)00157-1

14. Bradbury, M. and Baeyens, B., Near Field Sorption Data Bases for Compacted MX-80 Bentonite for Performance Assessment of a High-Level Radioactive Waste Repository in Opalinus Clay Host Rock, PSI Bericht 03-07, 124 p, 2003.

15. Committee on Separations Technology and Transmutation Systems, Nuclear Wastes: Technologies for Separations and Transmutation, National Academies Press, 1996.

16. Ruminin, V. G., Mironova, A. V., Pankina, E. B., Chernomorova, N. V. and Mysik, S. G., A Study of Diffusion and Sorption Properties of Cambrian Clays Using Radioactive Tracers (36Cl and 90Sr), Radiochemistry, Vol. 46, No. 4, pp 391-397, 2004, http://dx.doi.org/10.1023/B:RACH.0000039118.55499.7e

17. Cole, T., Bidoglio, G., Soupioni, M., O'Gorman, M. and Gibson, N., Diffusion Mechanism of Multiple Strontium Species in Clay, Geochimica et Cosmochimica, Vol. 64, No. 3, pp 385-396, 1999, http://dx.doi.org/10.1016/S0016-7037(99)00324-5

18. Carroll, S. A., Roberts, S. K., Crisceti, L. J. and O'day, P. A., Surface Complexation Model for Strontium to Amorphous Silica nad Goethite, Geochemical Transactions, Vol. 9, No. 2, 26 p, 2008.

19. Keramost a.s. KERAMOST, http://www.keramost.cz/, [Accessed: 05-April-2016] 
20. Gondolli, J. and Vecernik, P., The Uncertainities Associated with the Application of Through-diffusion, the Steady-state Method: A Case Study of Strontium Diffusion, Geological Society, London, Special Publications, pp 603-612, 2014, http://dx.doi.org/10.1144/SP400.3

21. Shackelford, C. D. and Moore, S. M., Fickian Diffusion of Radionuclides for Engineered Containment Barriers, Engineering Geology, Vol. 152, No. 1, pp 133-147, 2012, http://dx.doi.org/10.1016/j.enggeo.2012.10.014

22. Roy, W. R., Krapac, I. G., Chou, S. F. J. and Griffin, R. A., Batch-type Procedures for Estimating Soil Adsorption of Chemicals, Technical Resource Document, United States: Environmental Protection Agency, 100 p, 1992.

23. Limousin, G., Gaudet, J.-P., Charlet, L. and Szenknect, S., Sorption Isotherms: A Review on Physical Bases, Modeling and Measurement, Applied Geochemistry, Vol. 22, No. 2, pp 249-275, 2007, http://dx.doi.org/10.1016/j.apgeochem.2006.09.010

24. Shackelford, C. D., Laboratory Diffusion Testing for Waste Disposal - A Review, Journal of Contaminant Hydrology, Vol. 7, No. 3, pp 177-217, 1991, http://dx.doi.org/10.1016/0169-7722(91)90028-Y

25. Vopálka, D., Filipská, H. and Vokál, A., Some Methodological Modifications of Determination of Diffusion Coefficients in Compacted Bentonite, Material Research Society Proceedings, Vol. 932, pp 983-990, 2006, http://dx.doi.org/10.1557/PROC-932-11.1

26. Golder Associates, GoldSim Contaminant Transport Module, Manual, Version 1.30, GoldSim Technology Group, 285 p, 2002.

27. Box, M. J., A New Method of Constrained Optimization and a Comparison with Other Methods, The Computer Journal, pp 42-52, 1965, http://dx.doi.org/10.1093/comjnl/8.1.42

28. Vanýsek, P., Ionic Conductivity and Diffusion at Infinite Dilution, CRC Handbook of Chemistry and Physics, 90 ${ }^{\text {th }}$ Edition, CRC Press, 2009.

29. Tsai, S-C., Ouyang, S. and Hsu, C-N., Sorption and Diffusion Behavior of Cs and Sr on Jih-Hsing Bentonite, Applied Radiation and Isotopes, Vol. 54, No. 2, pp 209-215, 2001, http://dx.doi.org/10.1016/S0969-8043(00)00292-X

30. Carbal, P. and Engkvist, I., Compilation of Radionuklide Sorption Coefficients for Performance Assessment, SKB Technical Report TR-97-13, 67 p, 1997.

31. Vopálka, D., Lukin, D. and Vokál, A., Modelling of Processes Occurring in Deep Geological Repository - Development of New Modules in the GOLDSIM Environment, Czechoslovak Journal of Physics, Vol. 56, No. 1, pp D623-D628, 2006, http://dx.doi.org/10.1007/s10582-006-1074-6

32. Van Loon, L. R., Baeyens, B. and Bradbury, M. H., Diffusion and Retention of Sodium and Strontium in Opalinus Clay: Comparison of Sorption Data from Diffusion and Batch Sorption Measurements, and Geochemical Calculations, Applied Geochemistry, Vol. 20, No. 12, pp 2351-2363, 2005, http://dx.doi.org/10.1016/j.apgeochem.2005.08.008

33. Bradbury, M. and Baeyens, B., A Comparison of Apparent Diffusion Coefficients Measured in Compacted Kunigel V1 Bentonite with those Calculated from Batch Sorption Measurements and De (HTO) Data: A Case Study for Cs(I), Ni(II), Sm(III), Am(III), Zr(IV) and Np(V), Nagra Technical Report 02-17, 41 p, 2002.

34. Ochs, M., Talerico, C., Sellin, P. and Hedin, A., Derivation of Consistent Sorption and Diffusion Parameters and their Uncertainties for Compacted MX-80 Bentonite, Physics and Chemistry of the Earth, Vol. 31, No. 10-14, pp 600-609, 2006, http://dx.doi.org/10.1016/j.pce.2006.04.010

35. Katsumi, T., Ishmori, H., Onikata, M. and Fukagawa, R., Long-term Barrier Performance of Modified Bentonite Materials Against Sodium and Calcium 
Permeant Solutions, Geotextiles and Geomembranes, Vol. 26, No. 1, pp 14-30, 2008, http://dx.doi.org/10.1016/j.geotexmem.2007.04.003

36. Montes-H, G. G., Duplaya, J., Martinez, L., Geraud, Y. and Rousset-Tournier, B., Influence of Interlayer Cations on the Water Sorption and Swelling-shrinkage of MX80 Bentonite, Applied Clay Science, Vol. 23, No. 5-6, pp 309-321, 2003, http://dx.doi.org/10.1016/S0169-1317(03)00130-3

37. Choi, J. W. and Oscarson, D. W., Diffusive Transport Through Compacted Na- and Ca-bentonite, Journal of Contaminant Hydrology, Vol. 22, No. 3-4, pp 189-202, 1996, http://dx.doi.org/10.1016/0169-7722(95)00081-X

38. Aldaba, D., García-Gutiérez, M., Rigol, A. and Vidal, M., Comparison of Laboratory Methodologies for Evaluating Radiostrontium Diffusion in Soils: Planar Source Versus Half-cell Methods, Science of the Total Environment, Vol. 408, No. 23, pp 5966-5971, 2010, http://dx.doi.org/10.1016/j.scitotenv.2010.05.035 